\title{
Does the Underwriter Reputation Affect the Pricing of Local Government Bonds in China?
}

\author{
Hongdan $\mathrm{Ji}^{1,2}$ \\ ${ }^{1}$ School of Public Finance and Taxation, Central University of Finance and Economics, Beijing, China \\ ${ }^{2}$ School of Public Finance and Administration, Guangxi University of Finance and Economics, Nanning, China \\ Correspondence: Ji Hongdan, School of Public Finance and Taxation, Central University of Finance and \\ Economics, 39 South College Road, Haidian District, Beijing 100081 China.
}

\author{
Received: May 6, 2020 \\ Accepted: May 22, 2020 \\ Online Published: June 4, 2020 \\ doi:10.5539/ibr.v13n7p45 \\ URL: https://doi.org/10.5539/ibr.v13n7p45
}

\begin{abstract}
As the product of the combination of fiscal and financial, local government bonds should also follow the pricing mechanism of the securities market even under the special financial system in China. This paper uses Heckman's two-stage model to investigate whether the mechanism of underwriter reputation affects the pricing of local government bonds. The empirical results show that local governments tend to choose securities company underwriters with high reputation when they issue bonds with large scale, long maturity, and call right which have high degree of information asymmetry, and this tendency has an obvious time trend. However, high-reputation securities company underwriters failed to play the role of information intermediary to reduce the cost of local governments. On the contrary, implicit guarantees and government interventions induced the commercial banks to depress their quotations even leading to "interest rate upside down", which resulted in the lack of securities company underwriters. In order to play the mechanism of underwriter reputation to promote the marketization of local government bonds pricing, this paper proposes to eliminate government interference, guide underwriters to strengthen the construction of their reputation, promote the marketization of underwriting fees and strengthen the supervision of underwriters.
\end{abstract}

Keywords: local government bonds, pricing, underwriter reputation, implicit guarantees, government interventions

\section{Introduction}

\subsection{Background of the Research}

At present, issuing local government bonds has become the only way of debt financing for local governments in China, and the sustainable development of local government bonds market directly affects the ability of national governance. However, in the early stage of the development of the local government bonds market, due to the existence of non-market factors such as implicit guarantees, government intervention, formalization of credit rating and inadequate disclosure of information, the current pricing of local government bonds shows many phenomena contrary to theoretical expectations. Firstly, the credit rating of local government bonds is all AAA, which leads to the same interest rate of some bonds issued by different issuer; Secondly, local government bonds of different maturities do not show an absolute interest rate term structure trend, such as the average interest rates of 7, 10,15 and 20-year bonds are lower than those of 5-year bonds; Thirdly, according to the theory, revenue bonds face higher risks than general bonds, but the coupon rate of revenue bonds in the same period is not absolutely higher than that of general bonds. Fourth, the problem of "interest rate hanging upside down" is serious. In 2016-2019, the proportion of bonds with a negative spread is $9.28 \%$, especially 30 -year bonds with the most serious problem (Note 1).

The distorted pricing of local government bonds not only directly damages the interests of investors, but also violates the attributes of local government bonds as financial products. Therefore, how to achieve the market-oriented pricing of local government bonds in China has become the focus and difficulty of current academic circles. Based on the underwriter reputation theory in the securities market, this paper examines whether the underwriter reputation plays the role of information authentication and signal transmission to affect the pricing of local government bonds, and then puts forward suggestions to promote the market-oriented pricing 
from the perspective of underwriters.

\subsection{Main Contributions}

The main contributions of this paper are as follows: 1)Using foreign municipal bond theory and practical experience to investigate the role of underwriter reputation mechanism in the pricing process of local government bonds in China; 2)Using Heckman's two-stage model to overcome the endogenous selection bias of multiple linear regression model.

\section{Literature Review and Theoretical Hypotheses}

\subsection{Literature Review}

The underwriter reputation theory was first put forward by booth \& Smith (1986), that is, underwriters which have the function of information acquisition and authentication, are the information excavator and producer, and help to reduce the information asymmetry in the capital market and affect the price of securities. However, due to the potential conflict of interests between underwriters and investors, the opportunistic tendency of underwriters to maximize their interests will make the underwriters' certification information face the problem of credibility. Even if the underwriters do not have such opportunistic behavior, they will inevitably make "honest mistakes". In this case, the underwriter reputation becomes an important basis for investors to judge their "credibility"(Liu, Yin, \& Yi, 2005). Therefore, the underwriter reputation theory holds that the better the underwriter reputation is, the higher its credibility is, and the more investors can agree with the securities price which is evaluated and certified by the underwriter. Chemmaunr \& Fulghier (1994) further extended the ideas, and obtained the positive relationship between the quality of the IPO enterprise and the underwriter reputation by constructing a two-period dynamic game model (i.e. Chemmaunr-Fulghier model) .

A large number of theories and literature have proved that the underwriter with high reputation as an information intermediary can significantly reduce the information asymmetry and affect the price of securities. For example, the underwriter reputation is significantly related to the short-term and long-term performance of IPO, the initial and long-term performance of closed-end funds, the quality of corporate bonds, and the price of nonconvertible industrial bonds(Carter \& Manaster, 1990; Carter, Dark, \& Singh, 1998; Booth, 2004; Fang, 2005; Miller \& Robert, 2000). With the increasing scale of municipal bonds, some scholars have also examined the role of underwriter reputation in the municipal bond market. Peng and Brucato (2004) argued that the municipal bond market faces more serious information asymmetry than the corporate bond market, and underwriters of high reputation can better carry out information dissemination activities based on their advantages, to reduce the financing cost of municipal bond. Similarly, Daniels and Vijayakumar (2007) proposed that issuers should choose high reputation underwriters to reduce financing costs. In particular, because the revenue bonds that rely on the repayment of project-specific proceeds face more serious information asymmetry than the general bonds, the revenue bonds that are issued on a large scale, with a lower credit rating, and by the agreement are more likely to employ underwriters of high reputation (Daniels \& Ejara, 2009).

In China, due to excessive government regulation in the early stage, scholars did not realize the information intermediary role of underwriters in the securities market. With the securities market continuous improvement and development, the market-oriented pricing mechanism advocated has objectively accelerated the speed of information disclosure and information dissemination, making the underwriters' role of information authentication and signal transmission increasingly prominent. The conclusions of $\mathrm{He}$, Zhou, and $\mathrm{Lu}$ (2016), Zhao and Sun (2016), Lin, Liu, and Zhao(2019) support the underwriter reputation mechanism in urban investment bonds, IPO under-pricing, corporate bonds, and other markets,respectively. However, there is no study on the role of underwriter reputation in the analysis of local government bonds pricing so far. These deficiencies are the starting point of this study and the problems to be solved.

\subsection{Research Hypotheses}

Although local government bonds is a way for local governments to raise financial funds, its essence is a financial product, which should follow the principle of market-oriented pricing, to realize the sustainable development of the local government bonds market. However, under the special political and financial system in China, whether the underwriter reputation can alleviate the information asymmetry of the local government bonds market and reduce the financing cost still needs further verification. According to the underwriter reputation theory and the conclusion of existing literature, hypothesis 1 and hypothesis 2 of this paper are proposed.

Hypothesis 1: The larger the issue scale, the longer the term, and the callable revenue bonds, the more serious the information asymmetry problem, so they are more inclined to choose underwriters with high reputation. 
Hypothesis 2:Under the control of other factors, underwriters with high reputation can alleviate the information asymmetry of the local government bonds market, and then significantly reduce the cost of local government bond financing.

\section{Research Design}

\subsection{Variable Selection}

\subsubsection{Dependent Variable}

Combing the relevant literature of the influencing factors of municipal bond interest rate, it is found that the dependent variables are mainly divided into two categories: interest cost and issuance spread. Interest cost includes net interest cost (NIC) and real interest cost (TIC), which directly depicts financing cost. The issuance spread refers to the part of risk premium that investors bear to purchase municipal bonds. Generally, the yield of a treasury bond is regarded as the risk-free interest rate. Therefore, the issuance spread is equal to the coupon rate minus the maturity yield of treasury bonds with the same term on the issue date.

Considering that all the local government bonds in China are tax-free bonds, and the issuance cost is a fixed proportion of the issuance scale, and the issuance spread can better reflect the risk compensation for investors, therefore, this paper selects the issuance spread of local government bonds as the dependent variable.

\subsubsection{Independent Variables}

The main explanatory variable of this paper is underwriter reputation, which is ranked according to the market share of underwriting local government bonds by market share ranking method (M-W)(Note 2). At present, the underwriters of local government bonds in China are mainly commercial banks, supplemented by securities company, with a strong color of government intervention. According to the research of Ba, Li and Zhang(2019), the phenomena that local government linking treasury cash management bidding with bond underwriting volume existed in the underwriting process of local government bonds. Local government has absolute pricing power because of its mastery of financial deposits and local resources (Wang \& Fang, 2018), which makes commercial banks violate the market-oriented pricing mechanism and lower the bid. With the continuous improvement and development of local government bonds market in China, the number and share of securities companies participating in underwriting are increasing gradually, which fully shows that the monopoly of commercial banks has been broken in the underwriting process, and the financial intermediary role of securities companies has begun to play a role in it. Given the above considerations, this paper mainly examines the role of underwriter reputation of securities company. If there are top ten securities company underwriters among the leader underwriters, they are considered as underwriters with high reputation, which can theoretically alleviate the degree of information asymmetry and reduce the interest rate.

At the same time, to control the impact of other factors on local government bonds, following the idea that risk premium equals credit risk premium plus liquidity risk premium and market risk premium (Fisher, 1967), we also added indicators reflecting characteristics of the bond, ability of issuer, risk of market and other characteristics. However, since the credit rating of local government bonds is all AAA, which is not referential, and the rankings of local government credit quality issued by relevant research institutions are inconsistent, the impact of credit rating is not considered here alone. Besides, due to the overall downturn of the secondary market of the local government bonds, the impact of liquidity risk was not considered temporarily. The specific variable description is shown in Table 1. 
Table 1. Variable Description

\begin{tabular}{|c|c|c|c|c|}
\hline Variable Type & Variable Name & $\begin{array}{l}\text { Variable } \\
\text { Symbol }\end{array}$ & Variable Definition & $\begin{array}{l}\text { Expected } \\
\text { Symbol }\end{array}$ \\
\hline $\begin{array}{l}\text { Dependent } \\
\text { Variable }\end{array}$ & Issuance Spread & Spread & $\begin{array}{l}\text { The difference between the coupon rate of bonds } \\
\text { issued and the maturity yield of treasury bonds with } \\
\text { the same term on the issuance date }\end{array}$ & \\
\hline $\begin{array}{l}\text { Key Independent } \\
\text { Variables }\end{array}$ & $\begin{array}{l}\text { Underwriter } \\
\text { Reputation }\end{array}$ & Rep & $\begin{array}{l}\text { a dummy variable. If there are top ten underwriters of } \\
\text { securities companies among the lead underwriters, the } \\
\text { value is } 1 \text {, otherwise it is } 0\end{array}$ & $+/-$ \\
\hline \multirow{5}{*}{ Bond Variables } & Bond Scale & Scale & The size of bond issuance, take the logarithm & $+/-$ \\
\hline & Issuance Term & Mat & Term of bond & + \\
\hline & Bond Type & Type & $\begin{array}{l}\text { a dummy variable, } 1 \text { for revenue bonds and } 0 \text { for } \\
\text { general bonds }\end{array}$ & + \\
\hline & Call Right & Call & $\begin{array}{l}\text { a dummy variable, } 1 \text { for revenue bonds and } 0 \text { for } \\
\text { general bonds }\end{array}$ & + \\
\hline & Year of Issuance & Year19 & $\begin{array}{l}\text { If the bonds issued in } 2019 \text {, the value is } 1 \text {, otherwise it } \\
\text { is } 0 .\end{array}$ & \\
\hline \multirow{4}{*}{ Issuer Variables } & $\begin{array}{l}\text { Financial } \\
\text { Self-Sufficiency } \\
\text { Rate }\end{array}$ & Fis & $\begin{array}{l}\text { Local general public budget revenue divided by } \\
\text { general public budget expenditure, lag } 1 \text { period }\end{array}$ & - \\
\hline & Per Capita GDP & Gdp & GDP Per capita , lag 1 period & - \\
\hline & Debt Rate & Deb & $\begin{array}{l}\text { Local year-end debt balance divided by GDP, lag } 1 \\
\text { period }\end{array}$ & + \\
\hline & Investment Ratio & Inv & $\begin{array}{l}\text { Total investment in local fixed assets divided by GDP, } \\
\text { lag1 period }\end{array}$ & $+/-$ \\
\hline \multirow{3}{*}{ Market Variables } & $\begin{array}{l}\text { Risk-free Interest } \\
\text { Rate }\end{array}$ & Rate & $\begin{array}{l}\text { Yield to maturity of one-year treasury bonds one } \\
\text { working day before the issuance date }\end{array}$ & + \\
\hline & Shibor & Shi & $\begin{array}{l}\text { Shanghai interbank offered rate. Take the shibor of } \\
\text { one working day before the issuance date }\end{array}$ & + \\
\hline & Inflation Rate & Cpi & $\begin{array}{l}\text { Measured by the consumer price index of the month } \\
\text { before the issuance date }\end{array}$ & + \\
\hline
\end{tabular}

\subsection{Model Selection}

\subsubsection{Heckman's Two-Stage Model}

The main explanatory variable is the underwriter reputation, which is judged by whether there are the top ten securities companies among the leader underwriters. However, the choice of underwriters may not be an exogenous variable or even related to factors such as bond issuance size, issuance period, whether including rights or not. If OLS is used to estimate the impact of underwriter reputation on bond spreads, the regression coefficient will be biased. Therefore, to avoid endogenous selection bias (selectivity bias), Heckman's two-stage model (Heckman, 1979), which includes the underwriter selection equation and influencing factor equation of bond spread, is used for estimation based on Daniels et al (2007).

$$
\begin{gathered}
\operatorname{Rep}_{\mathrm{i}}^{*}=\gamma^{\prime} Z_{\mathrm{i}}+\varepsilon_{\mathrm{i}} \\
\operatorname{Spread}_{\mathrm{i}}=\beta^{\prime} \chi_{\mathrm{i}}+\delta \operatorname{Re} \mathrm{p}_{\mathrm{i}}+\mu_{\mathrm{i}}
\end{gathered}
$$

Note. The first equation is a probit regression model, which is used to estimate the probability of whether the issuer chooses a high-reputation underwriter. Re $\mathrm{p}^{*}$ represents the unobservable potential earnings variable obtained by the selection of high-reputation underwriters; $\operatorname{Re} p_{i}$ is the observable underwriter selection; $Z_{i}$ is a 
group of variables that affect the underwriter selection; $\operatorname{Re} p_{i}=1$ (if $\operatorname{Rep}_{\mathrm{i}}>0$ ), $\operatorname{Re} \mathrm{p}_{\mathrm{i}}=0$ (otherwise).

The second equation is used to capture the relationship between bond spread and underwriter reputation, as well as other control variables. $\chi_{i}$ is a set of exogenous variables, $\varepsilon_{i}$ and $\mu_{i}$ are disturbance terms of normal distribution.

Considering that the disturbance terms in the two equations are correlated, it will produce biased coefficients if the second regression equation directly uses OLS estimation. Therefore, the inverse mills ratio(namely IMR) obtained from probit regression is added to equation (2) to overcome the endogeneity, so that OLS regression can obtain the consistent parameter estimation.

According to the principle of Heckman's two-stage model, to avoid multicollinearity of OLS regression in the second stage, an index that affects underwriter selection but does not affect bond spread must be added to probit selection model in the first stage. Considering that the issuance year of bonds has no inevitable impact on bond pricing, but the proportion of securities companies as the leader underwriters increases significantly in 2019, so the dummy variable of the year is added in the first equation. Thus, the probit model and the multiple linear regression model are as follows :

$$
\begin{aligned}
& \text { Re } p_{i}=\partial_{0}+\beta_{1} \text { Mat }_{i}+\beta_{2} \text { Scale }_{i}+\beta_{3} \text { Type }_{i}+\beta_{4} \text { Call }_{\mathrm{i}}+\beta_{5} \text { Year19 } \mathrm{e}_{\mathrm{i}} \\
& \text { Spread }_{i}=\partial_{1}+\beta_{1} \operatorname{Rep}_{\mathrm{i}}+\beta_{2} \text { Scale }_{\mathrm{i}}+\beta_{3} \text { Mat }_{\mathrm{i}}+\beta_{4} \text { Type }_{i}+\beta_{5} \text { Call }_{i}+\beta_{6} \text { Fis }_{i}+\beta_{7} \operatorname{Gdp}_{\mathrm{i}} \\
& +\beta_{8} \text { Deb }_{\mathrm{i}}+\beta_{9} \operatorname{Inv}_{\mathrm{i}}+\beta_{10} \text { Rate }_{\mathrm{i}}+\beta_{11} \text { Shi }_{\mathrm{i}}+\beta_{12} \mathrm{Cpi}_{\mathrm{i}}+\beta_{13} \operatorname{Im~r}_{\mathrm{i}}+\eta_{\mathrm{i}}
\end{aligned}
$$

As shown in Table $1, \operatorname{Rep}_{\mathrm{i}}$ refers to the underwriter reputation value of bond $\mathrm{i}$, and equals 1 or 0 ; $\operatorname{Spread}_{\mathrm{i}}$ is the spread between bond $\mathrm{i}$ and the corresponding treasury bonds; Similarly, the $\mathrm{Mat}_{\mathrm{i}}, \mathrm{Scale}_{\mathrm{i}}$, Type $\mathrm{T}_{\mathrm{i}}$ and Call $\mathrm{are}_{\mathrm{i}}$ characteristics index of bond $\mathrm{i}$; $\mathrm{Fis}_{\mathrm{i}}, \mathrm{Gdp}_{\mathrm{i}}, \mathrm{Deb}_{\mathrm{i}}$ and $\mathrm{Inv}_{\mathrm{i}}$ are fiscal and economic index of corresponding issuer of bond $\mathrm{i}$; Rate $\mathrm{R}_{\mathrm{i}}, \mathrm{Sh}_{\mathrm{i}}$ and $\mathrm{Cpi}_{\mathrm{i}}$ are market index of corresponding period of bond $\mathrm{i}$. In addition, $\mathrm{Imr}_{\mathrm{i}}$ is equal to the probability density function of the standard normal distribution divided by the cumulative distribution function obtained by equation (3); $\mathrm{e}_{\mathrm{i}}$ and $\eta_{\mathrm{i}}$ are disturbance terms of equation (3) and equation (4), respectively.

\subsubsection{Sample Selection and Data Source}

Before 2018, the leader underwriters of local government bonds are all commercial banks, which have a strong nature of bank monopoly, so it is impossible to examine the information authentication and signal transmission role of securities underwriters in underwriting business, so the sample selected in this paper is local government bonds issued in 2018-2019. In addition, the following samples are carried out: (a) Because the financial and economic conditions of Shenzhen, Dalian, Qingdao, Ningbo, Xiamen and Xinjiang Construction Corps are quite different from those of the provinces, which are not comparable, the bond samples issued by them are excluded; (b) due to the lack of some data of Tibet Autonomous Region, the bond samples issued by them are excluded. Finally, 1702 samples were obtained.

The spread of local government bonds is obtained by subtracting the maturity yield of treasury bonds with the same term on the issue date published by China bond information network from the Coupon rate on the issuance date; The data of underwriter reputation is calculated by the underwriting shares of local government bonds based on WIND database; The characteristic data of local government bonds is derived from WIND database, and the repeated number of cross-market transactions is eliminated; The data of per capita GDP, debt ratio, financial self-sufficiency ratio and investment ratio are sorted out according to the data of WING database, considering that the local government's borrowing behavior is mainly based on the financial and economic situation of the previous year, and in order to reduce multicollinearity problems, these variables all lag one period; The Shibor data (overnight) come from WIND database, and uses Excel to match Shibor corresponding to bond issue date; CPI data comes from RESSET financial research database. In addition, to avoid the influence of outliers, all continuous variables are winsored with $1 \%$ and $99 \%$ quantiles. 


\section{Empirical Results and Analysis}

\subsection{Univariate Analysis}

Table 2. Descriptive statistics of variables

\begin{tabular}{|c|c|c|c|c|c|}
\hline Variables & $\begin{array}{l}\text { Number } \\
\text { of Samples }\end{array}$ & $\begin{array}{l}\text { Average } \\
\text { Value }\end{array}$ & $\begin{array}{l}\text { Standard } \\
\text { Deviation }\end{array}$ & $\begin{array}{l}\text { Minimum } \\
\text { Value }\end{array}$ & $\begin{array}{l}\text { Maximal } \\
\text { Value }\end{array}$ \\
\hline \multicolumn{6}{|l|}{ Full Sample } \\
\hline Spread & 1702 & 33.115 & 24.593 & -41.26 & 98.41 \\
\hline Type & 1702 & 0.703 & 0.457 & 0 & 1 \\
\hline Maturity & 1702 & 8.361 & 5.884 & 2 & 30 \\
\hline Call & 1702 & 0.016 & 0.125 & 0 & 1 \\
\hline Scale & 1702 & 3.065 & 1.389 & -0.511 & 5.684 \\
\hline Year 2019 & 1702 & 0.582 & 0.493 & 0 & 1 \\
\hline Underwriter Reputation & 1702 & 0.304 & 0.46 & 0 & 1 \\
\hline \multicolumn{6}{|c|}{ Samples of High-Reputation Underwriters } \\
\hline Spread & 517 & 32.313 & 25.06 & -41.26 & 98.41 \\
\hline Type & 517 & 0.683 & 0.466 & 0 & 1 \\
\hline Maturity & 517 & $8.954 * * *$ & 6.491 & 2 & 30 \\
\hline Call & 517 & $0.037 * * *$ & 0.188 & 0 & 1 \\
\hline Scale & 517 & $3.175 * *$ & 1.361 & -0.511 & 5.684 \\
\hline Year 2019 & 517 & $0.632 * * *$ & 0.483 & 0 & 1 \\
\hline \multicolumn{6}{|l|}{ Other Samples } \\
\hline Spread & 1185 & 33.465 & 24.389 & -41.26 & 98.41 \\
\hline Type & 1185 & 0.711 & 0.453 & 0 & 1 \\
\hline Maturity & 1185 & 8.103 & 5.582 & 2 & 30 \\
\hline Call & 1185 & 0.007 & 0.082 & 0 & 1 \\
\hline Scale & 1185 & 3.017 & 1.399 & -0.511 & 5.684 \\
\hline Year 2019 & 1185 & 0.56 & 0.497 & 0 & 1 \\
\hline
\end{tabular}

Note. Because the key explanatory variable of this paper is underwriter reputation, and the first stage model is underwriter selection, which is mainly related to bond characteristic variables, so we do not launch a detailed statistical description here, but compare the differences between the samples of high-reputation underwriter and other samples through univariate analysis.

It can be found from table 2 that the average spread of the high-reputation underwriters is slightly less than that of other samples, but not significant; The mean value of high-reputation underwriters of the maturity, call, scale and year 2019 are all greater than other samples, and are significant at $1 \%$ and 5\% confidence levels, respectively. It can be concluded initially that bonds with long term, large scale, and right are more likely to choose high-reputation underwriters, which suggests that there will be obvious endogenous problems in the general OLS regression. In addition, whether or not to choose underwriters with high reputation also has significant differences in the year of issuance. The above univariate analysis results preliminarily support hypothesis 1, but whether high-reputation underwriters can alleviate the information asymmetry and significantly reduce the spread of bonds still need further verification.

\subsection{Empirical Test Results}

Table 3 shows the results of the probit model of equation (3), which examined the factors affecting the probability of underwriter selection in the process of local government bonds issuance. The regression results are consistent with Daniels et al (2007) and others. The characteristics of large scale, long term, including redemption rights which expand information asymmetry make issuers prefer to choose high -reputation securities company underwriters. In addition, the coefficient of bond type is negative but not significant, which is inconsistent with the conclusion of Peng (2004) and others that high reputation underwriters should be selected to convey reliable information to investors due to the high degree of information asymmetry of revenue bonds, reflecting that the market participants haven't fully realized the essential difference between revenue bonds and general bonds at present. 
Table 3. Regression Results of Probit Model

\begin{tabular}{lll}
\hline Variables & Coefficient & Z value \\
\hline Scale & $0.054^{* *}$ & 2.09 \\
Maturity & $0.014^{* *}$ & 2.46 \\
Call & $1.07 * * *$ & 4.22 \\
Type & -0.098 & -1.26 \\
Year 2019 & $0.13 *$ & 1.91 \\
Constant & $-0.83^{* * *}$ & -6.46 \\
Pseudo R2 & 0.02 & \\
Forecast Accuracy & $70.21 \%$ & \\
Number of Samples & 1702 & \\
\hline Note. $* *, * *, *$ mean significant at $1 \%, 5 \%, 10 \%$ level respectively.
\end{tabular}

Table 4 shows the results of multiple linear regression of the second stage. Through the heteroscedasticity test of the model, the results reject the hypothesis of the same variance, so the robust standard error is used in the regression process, and there is no obvious multicollinearity problem in the model. Column (1) of Table 4 reports the effect of underwriter reputation and bond characteristics on spreads, and the coefficient of underwriter reputation is not significant. Column (2) and column (3) added variables of issuer characteristics and market risk respectively, and the regression coefficient of underwriter reputation was still not significant. This shows that the overall level of marketization of local government bonds in China is low, and the high-reputation securities company underwriters do not play the role of information authentication and signal transmission, so they can not reduce the financing cost of local government by following the rules of the capital market.

At the same time, the issuance scale, call right, inflation rate are significantly positively correlated with bond spread, while the local per capita GDP is significantly negative correlated with bond spread, which is in line with the theoretical expectations. However, the regression results of issuance maturity, bond type, financial self-sufficiency rate, debt rate, risk-free interest rate, Shibor, and other variables are inconsistent with existed research(Wang \& Fang, 2018; He, 2018; Liu, 2018). This result not only directly shows that the current pricing results of local government bonds in China are far from the theoretical expectations, but also further reflects the phenomenon of non-market pricing of local government bonds(Wang, 2018; Ba et al., 2019).

Table 4. Results of Multiple Linear Regression in the Second Stage

\begin{tabular}{|c|c|c|c|}
\hline Spread & (1) & (2) & (3) \\
\hline \multirow{2}{*}{ Underwriter Reputation (Rep) } & 0.80 & -0.09 & -0.43 \\
\hline & $(0.71)$ & $(-0.01)$ & $(-0.38)$ \\
\hline \multirow{2}{*}{ Type } & $-12.23 * * *$ & $-10.30 * * *$ & $-10.32 * * *$ \\
\hline & $(-8.35)$ & $(-6.87)$ & $(-5.51)$ \\
\hline \multirow{2}{*}{ Maturity } & $-1.07 * * *$ & $-1.25 * * *$ & $-1.32 * * *$ \\
\hline & $(-6.15)$ & $(-7.10)$ & $(-5.79)$ \\
\hline \multirow{2}{*}{ Call } & $43.64 * * *$ & $37.08 * * *$ & $35.48 * * *$ \\
\hline & $(4.97)$ & $(4.23)$ & $(2.72)$ \\
\hline \multirow{2}{*}{ Scale } & $3.02 * * *$ & $2.91 * * *$ & $2.94 * * *$ \\
\hline & $(5.72)$ & $(5.48)$ & $(3.63)$ \\
\hline \multirow{2}{*}{ Per Capita GDP } & - & $-0.94 * * *$ & $-1.06 * * *$ \\
\hline & & $(-3.53)$ & $(-3.98)$ \\
\hline Financial Self-Sufficiency Rate & - & $\begin{array}{l}-1.12 \\
(-0.35)\end{array}$ & $\begin{array}{l}-1.40 \\
(-0.49)\end{array}$ \\
\hline \multirow{2}{*}{ Investment Ratio } & & 3.26 & 3.03 \\
\hline & - & $(1.31)$ & $(1.22)$ \\
\hline \multirow{2}{*}{ Debt Ratio } & - & 0.22 & 0.20 \\
\hline & & $(1.10)$ & $(1.03)$ \\
\hline Inflation Rate & - & - & $\begin{array}{l}2.86^{* *} \\
(2.52)\end{array}$ \\
\hline \multirow{2}{*}{ Shibor } & & & $-4.58 * * *$ \\
\hline & - & - & $(-3.49)$ \\
\hline \multirow{2}{*}{ Risk-Free Rate } & - & - & 3.50 \\
\hline & & & $(0.97)$ \\
\hline Inverse Mills ratio (IMR) & $72.72 * * *$ & $61.16^{* * *}$ & $61.07 * * *$ \\
\hline Number of samples & $\begin{array}{l}(6 . / 8) \\
1702\end{array}$ & $\begin{array}{l}(5.63) \\
1702\end{array}$ & $\begin{array}{l}(3.47) \\
1702\end{array}$ \\
\hline Adjusted R2 & 0.285 & $\begin{array}{l}1702 \\
0.307\end{array}$ & $\begin{array}{l}1702 \\
0.318\end{array}$ \\
\hline
\end{tabular}




\subsection{Robustness Test}

This paper makes the following robustness tests: (1) To more intuitively reflect the influence of underwriter reputation on the financing cost of local government bonds, the paper takes the coupon rate at the time of issuance as the dependent variable, and the definition of underwriter reputation and other explanatory variables are consistent with the benchmark regression; (2) To make the variable of underwriter reputation more authoritative, the securities companies rated AA in the classification results of securities companies published by China Securities Regulatory Commission(CSRC) in 2018 and 2019 will be regarded as high-reputation underwriters (Note 3). If there are AA level securities company underwriters in the main underwriters of local government bonds, the dummy variable of underwriter reputation equals 1 , otherwise 0 , and other variables remain unchanged. In the two robustness tests, except for the change of some indexes, the regression results are consistent with the benchmark regression. Whether the explained variable is changed to the coupon rate or the definition of underwriter reputation is changed, the underwriter with high reputation does not significantly reduce the financing cost of local government bonds. That is to say, the underwriter reputation mechanism didn't play the role of information identification and signal transmission. Due to the length of the article, the results of the robustness test are not reported here.

\section{The Deep Mechanism of the Ineffectiveness of Underwriter Reputation Mechanism}

\subsection{Implicit Guarantee}

Although the central government in China has clearly put forward the principle of no assistance to local governments, but the theory holds that the central government pursuing the maximization of social welfare has a strong motivation to help local governments when they are on the brink of bankruptcy, to avoid causing greater political costs (Persson \&Tabellini, 1996; Bordegnon et al, 2001)). Therefore, the expectation of the central government inevitably forms the implicit guarantee to the local government's debt. Under the recognition of "rigid payment" of local governments debt, investors not only form the illusion that the sub-sovereign credit of local government equals to the national sovereign credit, but also mistakenly equate the credit of local government bonds with the issuer's credit, so that the interest rate of local government bonds is close to the interest rate of treasury bonds.

\subsection{Government Intervention}

To minimize the cost of debt financing, local governments use their financial resources to intervene in the issuance and pricing of local government bonds. In detail, some provinces have linked the underwriting volume of local government bonds with the scalar amount of the treasury cash fixed deposits, which makes commercial banks compete to lower the bid price to obtain more financial special accounts, financial deposits and other resources, leading to the distortion of local government bonds prices.

\subsection{The Low Level of Marketization Leads to the Lack of Securities Companies}

Under the dual effects of implicit guarantee and government intervention, the local government bonds present non-market pricing results, which not only deprives the securities companies of the qualification as the lead underwriter, but also hinders the effectiveness of the securities companies in performing the information intermediary function. On the one hand, local governments and commercial banks have become "conspiracy" under the natural motivation of cooperation. In the process of public bidding for local government bonds, the bidding price determined by most securities companies according to the principle of market-oriented pricing is higher than that determined by the collusion game between local governments and commercial banks, resulting in the characteristics of bank monopoly in the underwriting business of local government bonds in a certain period, and depriving the securities companies of the qualification as the lead underwriters. On the other hand, the implicit guarantee factors of the central government cover up the real credit quality and default risk of local government bonds, then increase the difficulty of obtaining effective information. In addition, lower yield can not drive securities companies to implement necessary due diligence, information disclosure, and other intermediary activities.

In short, as the Figure 1 shows, the implicit guarantee from the central government and the government intervention from the local governments to the commercial banks have hindered the market-oriented issuance and pricing process of the local government bonds, which objectively restricted the securities companies from participating in the leader underwriting business of the local government bonds. At the same time, securities companies are not enthusiastic to underwrite local government bonds driven by the subjective interests. Therefore, the underwriter reputation mechanism in the capital market can not play the role of information intermediary in the local government bonds market in China. 


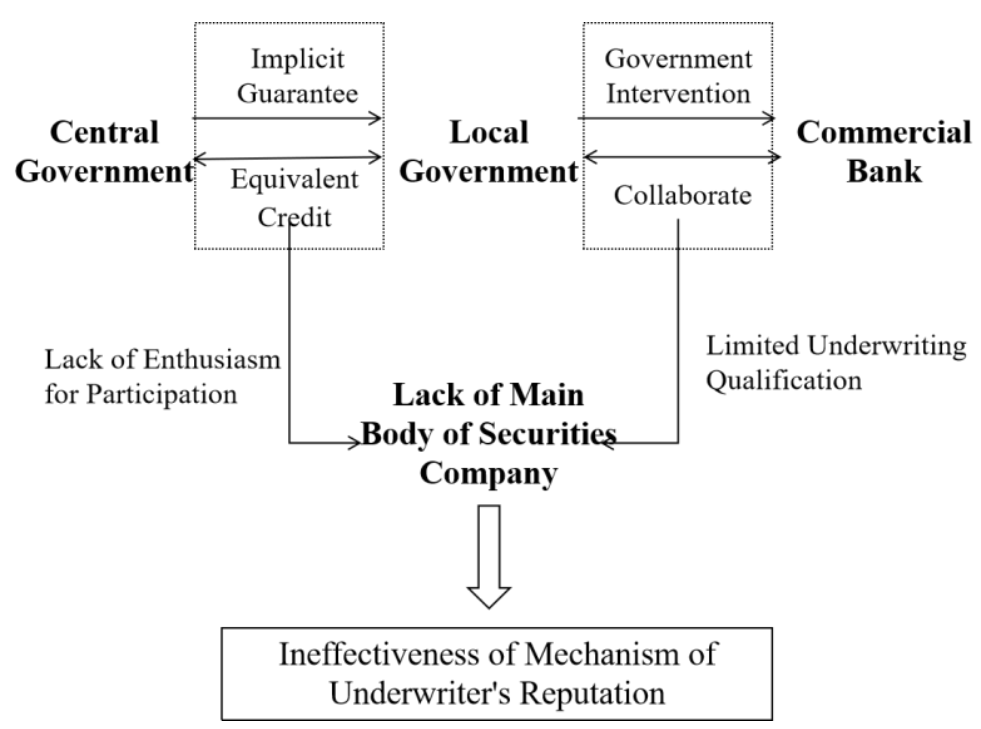

Figure 1. The Deep Mechanism of the Ineffectiveness

\section{Conclusions and Recommendations}

\subsection{Conclusions}

Based on the distorted pricing of local government bonds in China, this paper introduces the underwriter reputation mechanism in the securities market to investigate whether the high-reputation underwriters play the role of information authentication and signal transmission to reduce the financing cost of local government bonds. To overcome the endogenous selection bias that may exist in the multiple linear regression model, the Heckman's two-stage model is used to make a specific estimation. The results of benchmark regression and robustness test show that the bonds with large scale, long term, and call right which have high degree of information asymmetry are more inclined to choose securities company underwriters with high reputation. Meanwhile, the trend is more obvious in 2019, reflecting that local governments gradually pay more attention to the information intermediary role of underwriter reputation. But at present, due to the subjective and objective factors such as implicit guarantees, government interventions, and insufficient participation of securities companies, the high-reputation securities company underwriters fail to effectively play the reputation mechanism and significantly reduce the financing cost of local governments. Instead, the government interventions induce commercial banks to lower their quotations or even forming "interest rate hanging upside down". Although the behavior of lowering interest rate greatly reduces the financing cost of local government, it violates the regular of price discovery in the securities market, which will lead to the future trouble of "bad currency expelling good currency" in the long run. To promote the sustainable development of the local government bonds market in China, the underwriter reputation mechanism should be shaped. Only by playing the role of the information authentication and signal transmission of high-reputation securities company, can the market-oriented pricing of local government bonds be promoted by alleviating the information asymmetry between investors and issuers.

\subsection{Suggestions on Shaping the Underwriter Reputation Mechanism in China's Local Government Bonds Market}

In view of the non market pricing problem exacerbated by the lack of underwriter reputation mechanism caused by various subjective and objective factors in the initial stage of local government bonds in China, combined with the experience of other municipal bonds market and the securities market in China, this paper puts forward the following suggestions: 1)By eliminating government interventions and breaking the "conspiracy" between commercial banks and local governments, realize the benign competition between securities company and commercial banks; 2)The CSRC must implement the underwriting of securities company in local government bonds as a part of the classified evaluation of securities company, and guide the securities company to strengthen construction of their own reputation; 3)Try to release the limit range of underwriting fee and establish a free-floating system of underwriting fee; 4)The relevant departments should strengthen the supervision and restriction on the underwriters to avoid illegal and dishonest behaviors, so as to promote the formation of the underwriter reputation mechanism in local government bonds market in China. 


\section{References}

Ba, S. S., Li, Y. X., \& Zhang, B. (2019). A study on the influencing factors of local government bonds pricing-based on the perspective of the relationship between bank and government. Studies of International Finance, 7, 76-86.

Booth, J. R., \& Smith, R. I. (1986). Capital raising, underwriting, and the certification hypothesis. Journal of Financial Economics, 15, 261-281. https://doi.org/10.1016/0304-405X(86)90057-7

Booth, L. C. (2004). Underwriter reputation and aftermarket performance of closed-end funds. Journal of Financial Research, 27, 539-557. https://doi.org/10.1111/j.1475-6803.2004.00107.x

Carter, R. B., Dark, F. H., \& Singh, A. K. (1998). Underwriter reputation, initial returns, and the long-run performance of IPO stocks. The Journal of Finance, 53, 285-311. https://doi.org/10.1111/0022-1082.104624

Carter, R., \& Manaster, S. (1990). Initial public offerings and underwriter reputation. The Journal of Finance, 45, 1045-1067. https://doi.org/10.1111/j.1540-6261.1990.tb02426_3.x

Chemmanur, T. J., \& Fulghieri, P. (1994). Investment bank reputation, information production, and financial intermediation. The Journal of Finance, 49, 57-79. https://doi.org/10.2307/2329135

Daniels, K. N., \& Ejara, D. D. (2009). Impact of information asymmetry on municipal bond yields: an empirical analysis. American Journal of Economics \& Business Administration, 1, 11-20.

Daniels, K. N., \& Vijayakumar, J. (2007). Does underwriter reputation matter in the municipal bond market? Journal of Economics and Business, 59, 500-519. https://doi.org/10.1016/j.jeconbus.2006.09.002

Fang, L. H. (2005). Investment bank reputation and the price and quality of underwriting services. The Journal of Finance, 60, 2729-2761. https://doi.org/10.1111/j.1540-6261.2005.00815.x

He, D. (2018). An analysis of influential factors of credit price gap of municipal bonds in China. Journal of Hehai University (Philosophy and Social Sciences), 2, 83-92. https://doi.org/10.3876/j.issn.1671-4970.2018.01.013

He, Z. G., Zhou, Q., \& Lu, Y. W. (2016). An analysis of the impact of financial certification on bond financing costs - taking China's Urban Investment Bonds as an example. Securities Market Herald, 2, 63-71. https://doi.org/CNKI:SUN:ZQDB.0.2016-02-010

Heckman, J. (1979). Sample selection bias as a specification error. Econometrica, 47, 153-161.

Lin, W. F., Liu, Y. F., \& Zhao, Z. K. (2019). Underwriter rating and bond credit spread-empirical evidence from the "securities company classification supervision regulations". China Industrial Economics, 1, 174-192. https://doi.org/10.19581/j.cnki.ciejournal.2019.01.010

Liu, J. (2018). The Research on the local government project revenue bond.China Academy of Fiscal Sciences, 1-56. https://doi.org/CNKI:CDMD:2.1018.162985

Liu, J. H., Yin, B. C., \& Yi, X. J. (2005). An empirical analysis of the relationship between security underwriter reputation and IPO firm's quality in China. Finance \& Trade Economics, 3, 9-16. https://doi.org/CNKI:SUN:CMJJ.0.2005-03-003

Miller, L., \& Robert, E. (2000). Investment bank reputation and the underwriting of nonconvertible debt. Financial Management, 29, 21-34. https://doi.org/10.2307/3666283

Peng, J., \& Brucato, P. (2004). An empirical analysis of market and institutional mechanisms for alleviating information asymmetry in the municipal bond market. Journal of Economics and Finance, 28, 226-238. https://doi.org/10.1007/BF02761613

Wang, M., \& Fang, Z. (2018). The influencing factors of issuance cost on local government bonds in China -an empirical analysis of 3194 bonds in 2015-2017. Public Finance Research, 12, 35-47. https://doi.org/CNKI:SUN:CZYJ.0.2018-12-004

Wang, Z. G. (2018).Government intervention and "interest rate hanging upside down" in the issuance of local government bonds. Management Wold, 18, 25-35. https://doi.org/CNKI:SUN:GLSJ.0.2018-11-004

Zhao, Y., \& Sun, W. C. (2016). Underwriter reputation, institutional shareholdings, and IPO underpricing. Economic Management, 12, 112-131. https://doi.org/CNKI:SUN:JJGU.0.2016-12-012 


\section{Notes}

Note 1. Through sorting out the data of WIND database, I found that 307 of 3037 samples of local government bonds issued in 2016-2019 (excluding special samples) have an issuance spread less than 0, especially the average spread of 30 -year bonds is -12.05 .

Note 2. According to the existing research results, the rating methods of underwriter reputation mainly include tombstone announcement (C-M method) and market share ranking (M-W ranking system). However, since there is no tombstone announcement similar to that of the United States in China, the ranking of underwriter reputation in the existing literature in China is calculated according to the volume of underwriting business.

Note 3. The two methods of measuring underwriter reputation are different. In the benchmark regression, only five securities companies ranked in the top ten underwriters belong to high-reputation underwriters; In the robustness test, 12 and 10 securities companies which were rated AA in the classified evaluation by CSRC in 2018 and 2019 respectively are considered as high-reputation underwriters.

\section{Copyrights}

Copyright for this article is retained by the author(s), with first publication rights granted to the journal.

This is an open-access article distributed under the terms and conditions of the Creative Commons Attribution license (http://creativecommons.org/licenses/by/4.0/). 